\title{
6 Embracing Vulnerability
}

\author{
Magdalena Wróblewska
}

\begin{abstract}
Vulnerability, in the context of the museum, means the capacity to be in a state of openness, of exposure to attack or harm. It is a mode of awareness that can be developed in response to colonial, violent actions of the museum in the past, in hopes of overcoming it. Vulnerability in the museum can also be experienced by the visitor, within an exhibition or any other museum activity, when the contents touch difficult matters and the form enables emotional, intimate, and compassionate relationships with the story and its actors. Vulnerability is a training in receptivity that enables epistemic and ethical transformations, both of the museum and its visitors.
\end{abstract}

Keywords: receptivity, sensitivity, ethical transformation, ethics of failure, community relationships

Exposing weaknesses, doubts, and work-in-progress requires courage, but embracing such vulnerability leads to stronger, more inclusive institutions and individuals.

\section{The challenge}

Vulnerability, defined as "the quality or state of being exposed to the possibility of being attacked or harmed, either physically or emotionally," is one of the most desirable virtues of today's museums. Criticized for their traditional forms as violent, imperial, and dominating institutions of the modern system of knowledge, some museums have already developed the capacity for self-reflection and self-critique in their regular activities. Some have created new strategies, such as inviting criticism from the outside, for

Ariese, Csilla E., and Magdalena Wróblewska, Practicing Decoloniality in Museums: A Guide with Global Examples. Amsterdam, Amsterdam University Press 2022 DOI: 10.5117/9789463726962_CHo6 
instance by cooperating with an artist or curator or by establishing dialogues with engaged communities. However, vulnerability, understood as a mode of awareness and openness, requires even more - namely, a near-constant exposure and susceptibility to the risk of being attacked and harmed - as it emerges from imagining what it is to feel otherwise. ${ }^{1}$

Vulnerability is the capacity to imagine, feel, and see without excluding. It is the extension of work towards making the museum more accessible and more inclusive, to develop empathy for and identification with varied communities. It is also often defined as openness to an encounter with the 'other' as being different. Therefore, the real value of vulnerability is the possibility to transform existing perceptions of self, others, and the world. ${ }^{2}$ It may evoke a deepened sense of responsibility in museum staff as well as in visitors. It brings the promise of museums that are more equitable in their approaches, their content, and their engagement in power structures. ${ }^{3}$ Vulnerability is a virtue developed in communities to contest injustice, and it entails opening up to an ethical transformation.

Vulnerability is also the basis for learning and for understanding, as it facilitates connections and the building of a sense of community. Thus, it has become one of the key concepts in museum education nowadays, applied to both parts of the process. On the one hand, it is understood as an experience of 'being touched,' as an inherent part of the teaching-learning relationship, but vulnerability also requires letting down one's guard and abandoning the position of authority to reveal mistakes, struggles, uncertainties, and failures. This is an essential condition for continuing the growth and learning process, as opposed to the repetition of fixed knowledge.

Vulnerability additionally requires unprecedented openness to the voices of others, to the opinions and critiques of the museum's visitors, interested communities, and social activist groups. To remain relevant, museums must change their status from authorities of knowledge to a part of the learning community. Olga Viso, the director of Minnesota's Walker Art Center, concurred:

If museums want to continue to have a place, they must stop seeing activists as antagonists. They must position themselves as learning 
communities, not impenetrable centers of self-validating authority. If they do not, museums run the risk of becoming culturally irrelevant artifacts. ${ }^{4}$

Museums must train themselves in receptivity. Listening carefully to critical voices and uncomfortable stories and accepting them on equal terms is the only way for deep epistemic and ethical transformation to occur, which is necessary for the museum to be a relevant partner for communities.

\section{The change}

Vulnerability in a museum space may be an unexpected experience, when visitors encounter within the exhibition or in a museum program content that touches them, wounding or overwhelming them on a deep, personal level. It happens mostly when difficult matters, such as the Holocaust, childhood war experiences, or slavery are the subject of the exhibition, educational program, or publication offered by the museum. ${ }^{5}$ Such experiences can be evoked intentionally, when a painful past is recalled in its private, individual dimension, when the museum puts a face on history, for example by using the personal stories of victims. Feelings of close encounters, intimate relationships, and proximity to the life stories of other people open us up to new experiences and understandings of the past. However, it brings a risk of unwanted harm and pain on the part of the learner, as Tinning noted. ${ }^{6}$ Therefore, learning how to deal with uncomfortable moments and how to build on these experiences is an important part of such projects and should be facilitated by museum staff.

But vulnerability is an experience that is not only limited to the audience, but rather should embrace all parts of the process. One of the ways to improve vulnerability in the museum institution is collaboration with external experts and partners. Museums often invite artists, writers, or scholars for dialogues, cooperation, or exchanges of thoughts and experiences. Sometimes in the form of longer residencies. In the case of practicing decoloniality, however, there is always a risk of tokenizing, as described by Sumaya Kassim. ${ }^{7}$ Western museums may expect these invited artists, curators, or academics from formerly colonized countries or from their diasporas

4 Viso 2018.

5 Tinning 2018.

6 Tinning 2018.

7 Kassim 2017. 
to create or present work that would somehow 'mine the museum,' thus proving the self-reflectivity and self-critique of the institution. Namibian scholar and artist Nashilongweshipwe Mushaandja names this a 'practice of museuming,' when authorities "ask the victims of colonialism to handle its baggage." ${ }^{8}$ To avoid it, museums should not only carefully listen to the voices of invited collaborators and follow their observations and intuitions, but also make changes based on what was learned during such a project.

In an effort to embrace vulnerability, museums can also engage with communities, especially those who are disappointed or dissatisfied with the museum's activities or its profile. This creates a wide platform for vulnerability practices, if the institution is capable of listening to the voices of those disappointed and dissatisfied and able to adequately respond to them in future activities. In that case, vulnerability means being truly open for critique. It is actively dealing with uncomfortable opinions and situations instead of getting defensive and denying or hiding any problems. It is the courage to expose weaknesses, present infirmities, and share uncertainties, instead of holding on to an infallible position of authority. By listening to other (dissenting) voices and changing practices, museums can turn into instruments of social justice. ${ }^{9}$ Participatory approaches ${ }^{10}$ enable museums to change into more comfortable and fair institutions for those who for many reasons (e.g. social, health, cultural) may not feel like they are truly a part of them. Vulnerability requires truth and courage which are certainly not always comfortable. Yet, it helps to deepen relationships, if there is genuine engagement in all parts of the processes and experiences.

\section{The Museum of Others | Pitt Rivers Museum | Oxford, UK}

In 2016, the Pitt Rivers Museum (PRM) opened a permanent display of Christian Thompson's works in its Lower Gallery. In 2010, this artist invited to the museum exhibition had become the first Aboriginal Australian to be admitted into the University of Oxford and he began to work closely with the collections and staff of the Pitt Rivers Museum. Two years later, invited by curator Christopher Morton, in response to the museum's photograph collection he exhibited his new work there titled We Bury Our Own, which travelled internationally afterwards and received great acclaim. His later project presented in the Lower Gallery is a series of photographs titled The 
Museum of Others (2016). Thompson portrayed himself hidden behind and looking through the holes made in the eyes of the photographic images of several key figures in the British tradition of art and museum culture, including art critic John Ruskin, explorer Thomas Cook, anthropologist Walter Baldwin Spencer, and, last but not least, archaeologist Augustus Pitt Rivers (1827-1900), the founder of the museum.

Both projects refer to the PRM's history and collection. As a part of the University of Oxford, it was established in 1884 by Augustus Pitt Rivers to maintain the relationship of anthropological and archeological collections with the broad system of knowledge. He donated his international collection of about 22,000 objects on the condition that a permanent lecturer in anthropology must be appointed. Pitt Rivers and later donors sourced many items in the collection, such as the Benin bronzes, through violent and exploitative means recalled in the Sarr and Savoy report, ${ }^{11}$ including military punitive campaigns. Nevertheless, Pitt Rivers was highly esteemed in the scientific circles of his time for innovations in archaeological methodologies and in the museum display of archaeological and ethnological collections. Physically and structurally, the museum was, and still remains, a monument of colonialism, with 55,000 objects densely layered in dark wooden cases. The objects are still organized in line with the requests of the benefactor, according to type instead of cultural group or geographical location. This seems highly unusual and even controversial nowadays, as it makes it even more difficult for a visitor to trace the origins of particular objects.

Pitt Rivers was also one of the scientists responsible for the 'othering' of Aborigines; he actually built his career upon it. He believed in Social Darwinism and organized his collections from this explicitly racist and imperialist perspective. ${ }^{12}$ Therefore, a photograph of Thompson looking at visitors through the eyes of the museum's patron in one of the works from the series The Museum of Others, titled Othering the Ethnologist, Augustus Pitt Rivers, is truly moving and opens up a new perspective. The simple gesture of reversal raises important questions. Who is observing in the museum and who is being observed? Who is the 'other' to whom? With the faces of notable British colonial figures transformed into masks, Thompson evokes an uncanny feeling and causes discomfort in the viewer. He also touches a raw nerve in the institution, as his questions about the divisions and classifications of the world relate not only to the colonial past, but are distressingly relevant in the present museum setting. 
Figure 6.1 Othering the Ethnologist, Augustus Pitt Rivers

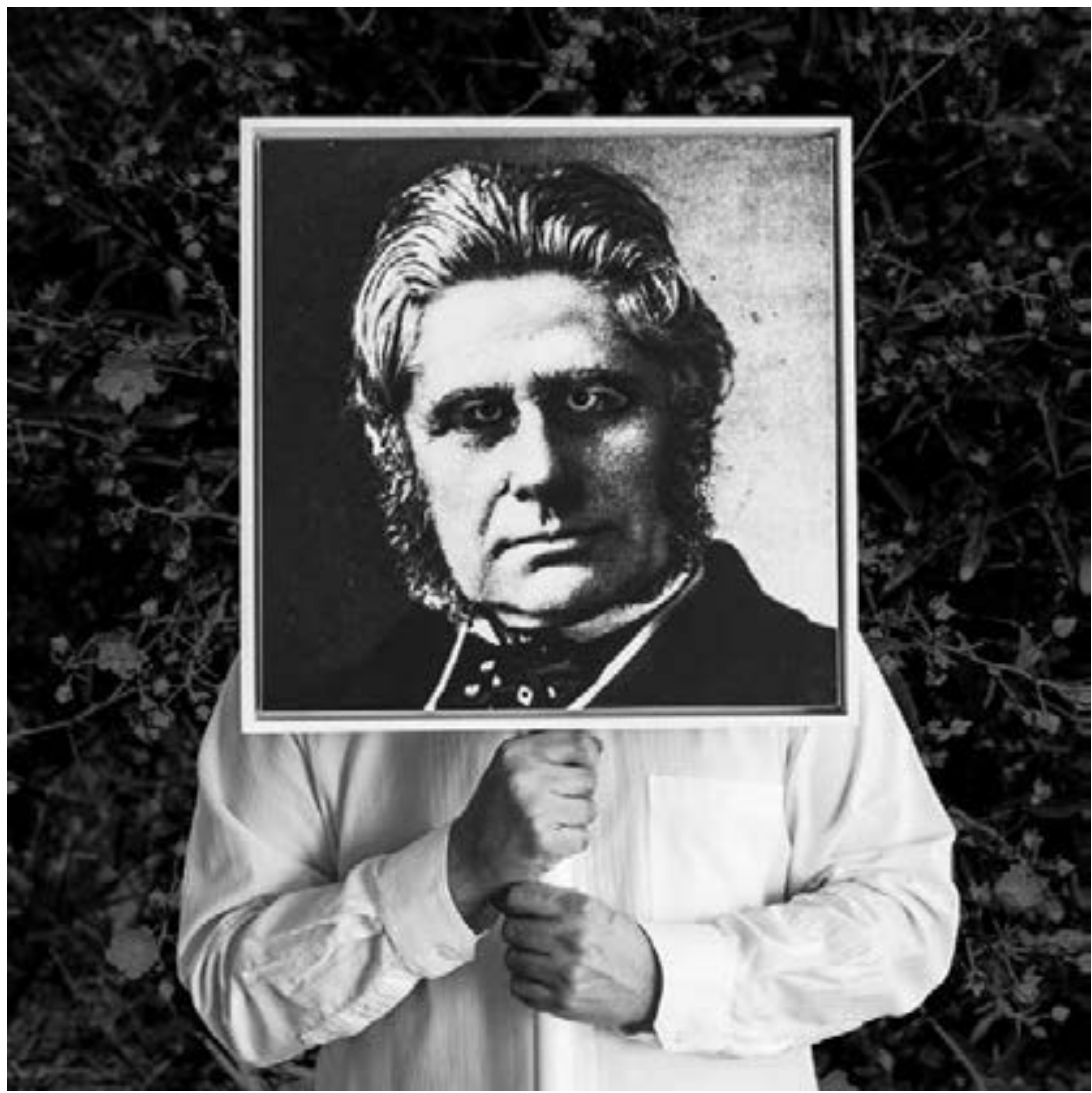

Christian Thompson, 2016; courtesy of the artist and the Yavuz Gallery

\section{Scaffold | Walker Art Center | Minneapolis, USA}

In 2015, the Walker Art Center (WAC) in Minneapolis acquired a public sculpture, Scaffold, by Sam Durant to place in the institution's sculpture garden that was to be opened in May 2017. The work, which had first been exhibited at $d O C U M E N T A 13$ in 2012 in Kassel, depicts gallows that represent seven major state-sanctioned executions in US history between 1859 and 2006. Its intent was to critique the persistence of the death penalty in American democracy as well as the racial dimension of the criminal justice system in the United States. However, part of it, which recalled a particular event in Minnesotan history, was seen by the local Native communities as a painful traumatic trigger. It was the re-creation of the 1862 scaffold 
used to put to death 38 Dakota Sioux men in the largest mass execution in American history.

The sculpture drew protests from the Native American community and, in response, Olga Viso, then director of the WAC, published a letter on 26 May 2017 admitting that she had failed to engage leaders of the Dakota and broader Native communities in advance of the work's siting. ${ }^{13}$ She apologized for the pain that the sculpture elicited and announced a consultation with Dakota community members. A few days later, after a three-hour mediation session attended by Durant, representatives from the Dakota Spiritual and Traditional Elders, the four federally recognized Dakota tribes, the WAC, and the Minneapolis Park and Recreation Board, the decision to remove the work was announced.

In a joint statement following the mediation session, the parties presented a plan for the sculpture's removal and ceremonial burning. Durant offered the sculpture and its intellectual property rights to the Dakota. A native construction company donated its services and dismantled the piece, beginning on 2 June, in a ceremony overseen by Dakota Spiritual and Traditional Elders, as the WAC donated an equivalent amount to fund the travel of elders to the ceremony. The wood was buried at Fort Snelling, where Dakotas were imprisoned following the 1862 US-Dakota War. As part of the final agreement, the WAC and Durant pledged never to reconstruct the work. The willingness and openness of all parties (the artist, Dakota elders, Minneapolis City officials, and the WAC staff and board) to engage in mediation helped to achieve a satisfying resolution.

This process would not have been possible if the old hierarchies, in which a museum's authority and the preservation of its collections are prioritized over the audience's feelings and expectations, had still been in place. As Viso said:

It is not easy to acknowledge one's blind spots. What I had hoped would be an opportunity for public education and 'truth to power' in the presentation of Scaffold was simply not possible because of the continuing historical trauma about an unreckoned-with colonial past. ${ }^{14}$

Additionally, Durant acknowledged that he had developed a new understanding of the considerable sensitivity surrounding the mass killing and he never would have included the Mankato gallows in such a work. The education 
Figure 6.2 Removal of Sam Durant's Scaffold following mediation and a joint decision

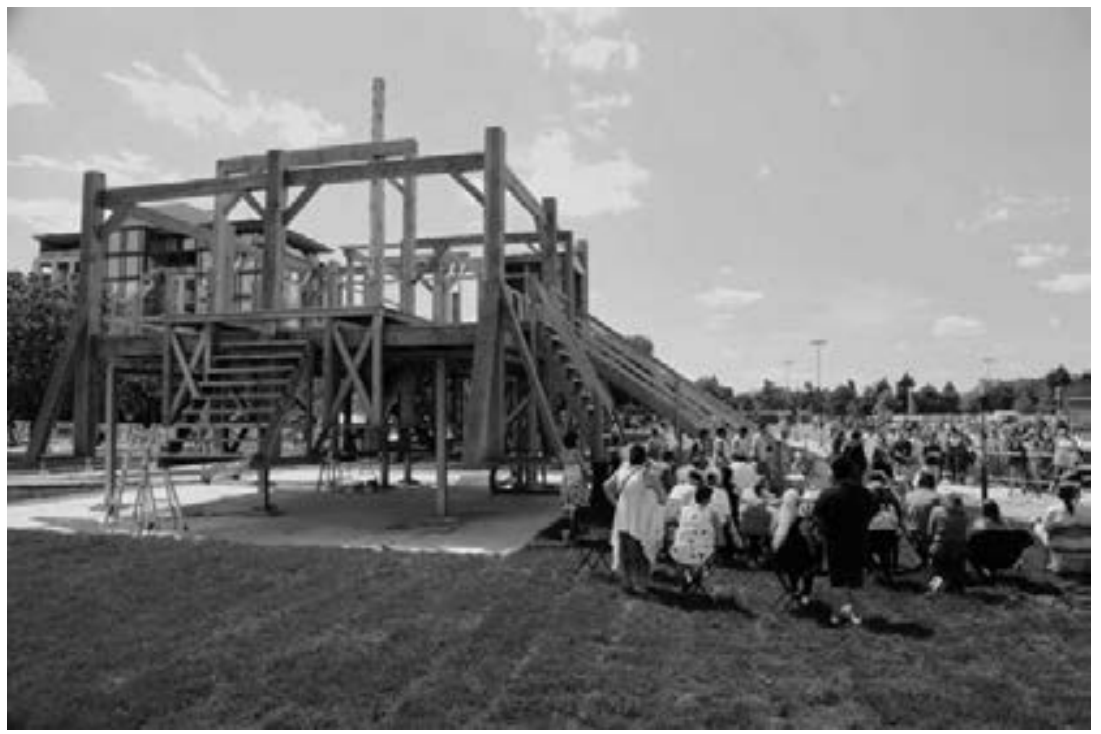

Walker Art Center; photo @ Walker Art Center, 2017

they both were open and willing to receive helped Viso and Durant to understand the Dakotas, and respond to their feelings and expectations. The whole process of negotiation was based on listening to painful truths, learning, and healing.

\section{Muzeum krytyczne (Critical Museum) by Piotr Piotrowski | Warsaw, Poland}

The book Muzeum krytyczne (Critical Museum) was published in 2011 by art historian, curator, and art critic, Piotr Piotrowski (1952-2015), professor at the Adam Mickiewicz University in Poznan and former director of the National Museum in Warsaw (NMW). It presents his concept of the 'critical museum,' developed originally for the main national institution in Poland, which he headed for nearly a year in 2009-2010. He resigned after the Board of Trustees rejected his program of reform of the then rather conservative and inert institution, even though his plan had initially been accepted by this same body a year before. Piotrowski's idea of the critical museum is rooted in the New Museology movement which aims at the denaturalization and 
Figure 6.3 Ars Homo Erotica exhibition

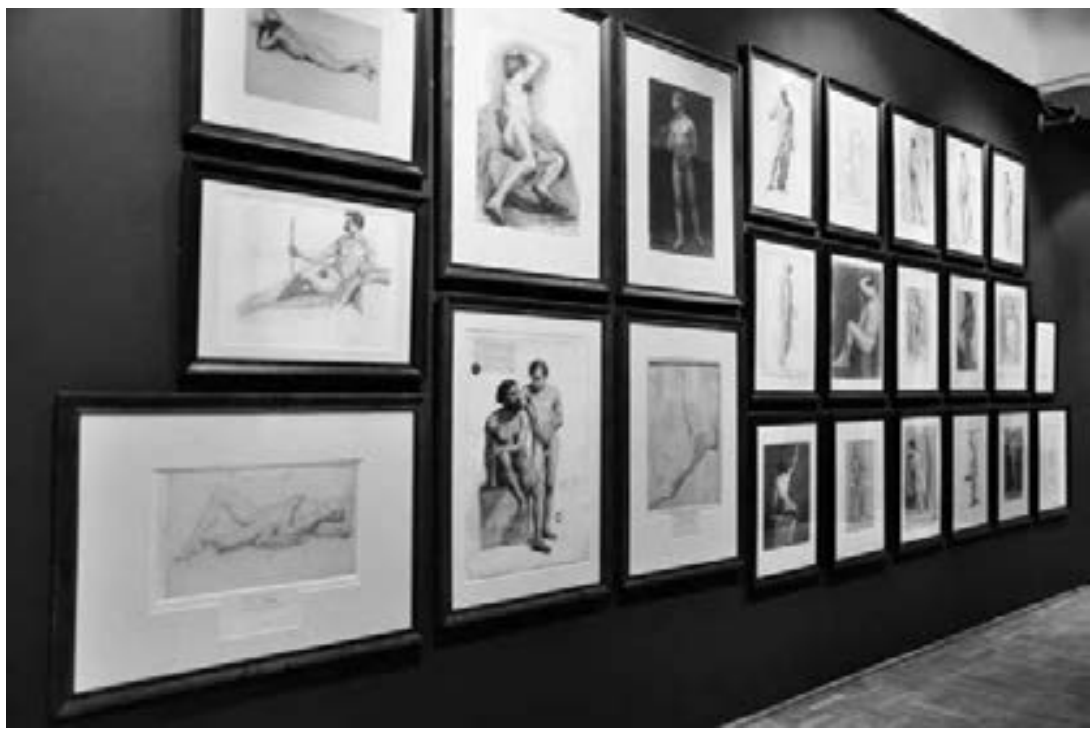

National Museum in Warsaw; photo by Raman Tratsiuk, 2010

denormalization of the museum institution whose foundations, organization, and collections are not politically neutral. ${ }^{15}$

Piotrowski started his reflections by recalling some of the most crucial postulates of the New Museology, such as a critical interpretation of a museum's history. A reflection on the imperial entanglements of particular museum institutions or even of the very concept of the museum, is the departing point of his idea of the critical museum. It follows for Piotrowski that every museum reflects universalism and a hegemony of empire, therefore absolutizing and objectifying the narratives it presents. This manifests itself mostly in the canon established through the collections. As a result, the canon can be a source of a complex, for instance when the collections of a peripheral museum, such as the National Museum in Warsaw, do not reflect the paradigm of central art institutions.

In his project, Piotrowski bravely presented the history of the National Museum in Warsaw as a kind of failure: due to political and financial reasons, museum authorities in this provincial city of the Russian Empire failed to create a collection according to the canon of European art. Moreover, this could be seen as a second failure, following upon the earlier project of 
the last Polish king, Stanisław August Poniatowski, who at the end of 18th century aimed to create such a collection that would be accessible to the public. Finally, the Nazi occupation of Poland and Warsaw during WWII and the extensive looting of the collections determined their current shape. Nevertheless, the galleries and permanent exhibitions of the NMW are shaped according to the dominant, Western canon of art and imitate it against all odds, despite the lack of 'masterpieces' in the collection which contains only a few examples of works by great masters that are recognizable to a wider audience. This provincial fixation which had been neglected for a long time was directly expressed by Piotrowski: "the National Museum in Warsaw cannot compete with the Prado or Hermitage, with the National Gallery in London or the Museum of Fine Arts in Budapest, it cannot compete with the Louvre, neither with its brand, nor with its collections, nor with the attractiveness of the place." ${ }^{16}$

For Piotrowski and his close collaborators, particularly Katarzyna Murawska-Muthesius, this exposure of weaknesses was a starting point for the plan of the new institution. Instead of imitating the established canon, they proposed to focus on local specificity and to build on that which was perceived as unattractive. For although the collection lacks paintings by old masters, it has a great selection of local modernist and contemporary art, of which the latter had not been the subject of any deeper interest before. This approach further allowed them to question the dominant canon from a peripheral position, taking inspiration from Dipesh Chakrabarty's Provincializing Europe. ${ }^{17}$ Afterwards, by leaving the issues of painful history behind them, they were able to define the current problems that the NMW should be dealing with: of an expanding metropole in Central-Eastern Europe, migration and minorities, and disadvantaged groups with difficult or limited access to the museum's offerings. The idea of the critical museum also implied questioning the 'national' dimension of the NMW as a remnant of 19th-century nationalism which has its own particular meanings in a country that ceased to exist and in a city that was incorporated into the Russian Empire. Such obsolete ideas were radically replaced by real and vital problems of contemporary society, like LGBTQ+ community rights. The exhibition Ars Homo Erotica, opened in June 2010, was the first broad presentation of the traditions and problems of homoerotic art in Poland..$^{18}$ And this was the only component of 
the ambitious and ground-breaking program that was executed, as several months later Piotr Piotrowski was forced to resign.

This example shows the (personal and professional) risk-taking that can be necessary to - try to - create institutional change. And how difficult it can be for institutions, particularly for their Boards of Trustees or leadership, to accept 'radical' change. It may be one thing in theory to agree to a new plan of reform, and then a whole different matter to accept in practice the necessary changes. All the more so if these changes include the replacement of higher-up staff and the need for management to essentially replace themselves. As this example illustrates, embracing vulnerability is one of the most challenging aspects of practicing decoloniality that requires extraordinary commitment to fully follow through.

\section{Voices from the Colonies | National Museum of Denmark | Copenhagen, Denmark}

The permanent exhibition titled Voices from the Colonies opened on 13 October 2017 in the National Museum of Denmark and is one of the first significant museum projects in the country about the colonial era and shares little-known information about this past. It is the result of long-running research and curatorial activities of the museum's team which previously led to the creation of the temporary exhibition The Danish West Indies Building the Colony (2011) as well as a website that presents the outcomes of the project. ${ }^{19}$ The core idea of that earlier exhibition was to reveal the structures, functions, and people of the colony. The newer permanent exhibition, however, is organized around a different idea: giving voice to the real historical people whose lives were determined or marked by colonialism. It concerns Denmark's colonial history in the Caribbean, India, West Africa, and Greenland from the perspective of individual biographies, the true-life paths of people who once lived in colonial realities. Their personal experiences are the main focus, even though this is a risky and difficult strategy for reasons detailed by Gayatri Chakravorty Spivak in her famous essay, "Can the Subaltern Speak?"2o

The exhibition is built up of dramatic stories of loss, fear, and violence. It touches the most extreme experiences, including enslavement, childhood trauma, broken families, and rape. But it does not present stigmatization or a one-sided vision of biographies, as it also highlights positive values and 
experiences like hope, power, and the fight for freedom. For example, the history of the colonial abuse and rape of an enslaved woman called Anna Catherina concludes with her seeking and receiving justice. But a happy end' is not the standard assumption and the exhibited examples were not selected in order to present an overly optimistic version of colonial histories. Instead, the main goal of the exhibition is to have visitors reflect on how colonialism in different ways has influenced the lives of people living under colonial regimes. Their strategy of putting names and faces onto history helps to create a sense of proximity to the protagonists. ${ }^{21}$ This enables compassion and empathy, if visitors are open to the histories and allow themselves to be affected by them on a deeper, personal level. This vulnerable experience of being touched or even wounded by the pain of historical others is crucial for a fundamental change in perception: colonial pasts are not closed and fixed, but continue to influence the lives of people across the globe.

The strength of the exhibition lies in avoiding a strict dichotomy between colonizers and those who were colonized. There are no distinctions between objects from the 'Danish' and the 'ethnographic' collections, successfully countering the idea that ethnographic objects are in the museum to represent the 'other.'22 This is further reinforced by presenting narrations of stories in the exhibition from multiple perspectives and argumentations. This is by no means to deny colonial injustices, violence, and pain, but to also illustrate how the colonial system inevitably ultimately harms both sides, not only those who were forced to sacrifice their lives producing coveted goods, but sooner or later also those who benefited from the profits. Such an approach enables vulnerable experiences and directs the visitors to reflect on current problems and debates about racism, as well as existent inequalities in all possible areas, including the economy, healthcare, and education.

\section{Further reading}

From Museum Critique to Critical Museum | edited by Katarzyna MurawskaMuthesius and Piotr Piotrowski | 2017

Looking Back Ahead: A Short History of Collaborative Work with Indigenous Source Communities at the Weltmuseum Wien | Claudia Augustat and Wolfgang Kapfhammer 2017 A Theory of Taking $\mid$ Dan Hicks $\mid 2020$ 


\section{Further examples}

\section{Getting In exhibition at the Immigration Museum}

Melbourne, Australia (2003-2015)

"More than 9 million people have migrated to Australia since 1788. Countless others have tried and failed. Since the 1800 s, various immigration policies have dictated who gets in. This exhibition shows how and why our immigration policies have changed. You'll see photographs, historical objects, and personal stories that show the effects of these policies on cultural diversity in Victoria. Central to the exhibition is an interactive theatre experience whereby visitors find themselves in the role of a government official charged with the responsibility of interviewing people applying to migrate to Australia, and discovering whether or not they 'get in'." 23

\section{JASMIM traditional Ukrainian music group at the Museu do Traje}

São Brás de Alportel, Portugal (since 2014)

“The vocal group 'JASMIN' was formed at the Museum of Sao Bras de Alportel, on the eve of Christmas in late 2014. We are all citizens of Ukraine, which we are proud of. But we chose São Brás de Alportel, a small place in Portugal, to live and work. We are very far from Ukraine, where we were born, but here in a foreign land we all strive to be happy. We formed our group to show our culture, our life, our traditions and the music we learned from childhood." ${ }^{24}$

With our thanks for this suggestion to Lorena Sancho Querol.

Biopolis artistic residency at the Botanic Gardens of the Jagiellonian University Krakow, Poland (2019)

"The intervention was a result of an art \& research residency during which the artist spent two weeks in the garden, accompanied by a research team, discovering the history of the institution, observing the way it functions, conducting interviews with its employees and discussing her observations during open meetings held in the garden. Grzywnowicz's intervention took a form of a contrafactual, alternative guided tour. It was the artist's response to the colonial structures of organising knowledge and exhibiting

23 As quoted from the Immigration Museum website. Available at https://museumsvictoria. com.au/immigrationmuseum/whats-on/getting-in/ (accessed 1 April 2021).

24 As quoted from the Museu do Traje website (in Ukrainian, machine-translated through Google). Available at https://www.museu-sbras.com/jasmim.html (accessed 1 April 2021). 
nature that she observed in the garden. The two crucial notions for this tour were, on one hand, the clear divisions between 'native' and 'exotic' (and value that is attributed to each of the categories); on the other hand - the peripheries, both of the topography of the garden itself, but also as a position from which the discourse of the institution is being constructed and reproduced, in relationship to the 'center': former colonial empires and botanical institutions that resulted from their colonial explorations." ${ }^{25}$ With our thanks for this suggestion to Aleksandra Janus.

In Our Backyard exhibition at the Gallery Gachet

Vancouver, Canada (2011)

"In Our Backyard is a photo storytelling series and art exhibition [...] While Canada has yet to obtain accurate statistics on the actual number of homeless, the nation wide population is estimated to be close to 300,000 , with an estimated population of 150,000 street-involved youth on any given day in this country. In Our Backyard showcases photos taken and art work created by seven youth participants, each member part of a team who identify themselves as the GVSS Youth Action Squad (YAS) - and have all experienced homelessness within the Greater Vancouver region. As part of the Homeless Voices/Call to Action Project 2011, the YAS which the youth have been involved in for the past 5 months has served as a foundation for these young people to find a voice in their community by sharing their stories and solutions to ending youth homelessness throughout the region.. ${ }^{26}$

\section{STIRRING exhibition at the Asia and Pacific Museum}

Warsaw, Poland (2020-2021)

"The exhibition, which completes a project run by the Asia and Pacific Museum in cooperation with the students of the Academy of Fine Arts in 2019, pairs museum objects with contemporary pieces. The students visited museum store rooms, participated in workshops and talked to curators. Each person chose one object which STIRRED their emotions (through its form, history, function, meaning) or which they wished to STIR back to life (return context and breathe life into museum objects

25 As quoted from the abstract of a presentation by Aleksandra Janus and Karolina Grzywnowicz, titled 'Native and Exotic: Towards Decolonizing a Botanical Garden' (presented during the conference Decolonizing Museum Cultures and Collections: Mapping Theory and Practice in East-Central Europe, Warsaw 2020).

26 As quoted from the Gallery Gachet website. Available at http://gachet.org/event/in-ourbackyard-youth-homelessness-photovoice-art-project-presents/ (accessed 1 April 2021). 
that were enclosed in cases and shelved away). The works created are the effects of these experiences. By juxtaposing museum objects with the works of young artists, we raise questions about the definitions and borders of art. [...] Through the juxtaposition of museum objects with the works of young artists, we confront the existing definitions and pre-conceptions about art. This juxtaposition and the authors' texts give an insight into the creative process, and inform the reception of the work and its interpretation." ${ }^{27}$

With our thanks for this suggestion to Barbara Banasik.

\section{References}

Augustat, Claudia, and Kapfhammer, Wolfgang. 2017. "Looking Back Ahead: A Short History of Collaborative Work with Indigenous Source Communities at the Weltmuseum Wien." Boletim Museu Paraense Emílio Goeldi: Ciências Humanas 12.3: 749-764.

Chakrabarty, Dipesh. 2000. Provincializing Europe: Postcolonial Thought and Historical Difference. Princeton and Oxford: Princeton University Press.

Gilson, Errin C. 2013. The Ethics of Vulnerability: A Feminist Analysis of Social Life and Practice. London and New York: Routledge.

Hicks, Dan. 2020. "A Theory of Taking." In Dan Hicks, The Brutish Museums: The Benin Bronzes, Colonial Violence and Cultural Restitution. London: Pluto Press. 18-24.

Kassim, Sumaya. 2017. “The Museum Will Not Be Decolonised." Media Diversified [essay], 15 November 2017. Available at https://mediadiversified.org/2017/11/15/ the-museum-will-not-be-decolonised/ (accessed 1 April 2021).

Katz, Meighen. 2019. Narratives of Vulnerability in Museums: American Interpretations of the Great Depression. London and New York: Routledge.

Leszkowicz, Paweł. 2010. Ars Homo Erotica. Warsaw: CePed.

Lidchi, Henrietta. [1997] 2010. "The Poetics and the Politics of Exhibiting Other Cultures." In Stuart Hall, ed. Representation: Cultural Representations and Signifying Practices. London; Thousand Oaks, CA; and New Delhi: Sage Publications. 151-222.

McLoughlin, Moira. 2014. Museums and the Representation of Native Canadians: Negotiating the Borders of Culture. London and New York: Routledge.

27 As quoted from the Asia and Pacific Museum website. Available at https://www.muzeumazji. $\mathrm{pl} / \mathrm{en} /$ temporary-exhibition/poruszenie/ (accessed 1 April 2021). 
Murawska-Muthesius, Katarzyna, and Piotrowski, Piotr, eds. 2017. From Museum Critique to Critical Museum. London and New York: Routledge.

Piotrowski, Piotr. 2011. Muzeum krytyczne [Critical Museum]. Poznań: Dom Wydawniczy Rebis.

Sandell, Richard, and Nightingale, Eithne, eds. 2012. Museums, Equality and Social Justice. London and New York: Routledge.

Sarr, Felwine, and Savoy, Bénédicte. 2018. The Restitution of African Cultural Heritage: Toward a New Relational Ethics. Paris: Ministère de la Culture.

Sebro, Louise. 2018. "Voices from the Colonies." Presented during the Annual Conference of the Research Center for Material Culture 'Reckoning with History: Colonial Pasts, Museum Futures, and Doing Justice in the Present.' YouTube [video lecture], 19 September 2018. Available at https:/www.youtube.com/ watch?v=si3uOz5wYGI (accessed 1 April 2021).

Simon, Nina. 2010. The Participatory Museum. Santa Cruz: Museum 2.o.

Spivak, Gayatri Chakravorty. 1985. "Can the Subaltern Speak?: Speculations on Widow-Sacrifice." Wedge 7/8: 120-130.

Tinning, Katrine. 2017. The Ambivalent Potentiality of Vulnerability: Museum Pedagogy in Exhibitions on Difficult Matters and its Ethical Implications. Lund: Lund University.

Tinning, Katrine. 2018. "Vulnerability as a Key Concept in Museum Pedagogy on Difficult Matters." Studies in Philosophy and Education 37.2: 147-165.

Valley, Geer. 2019. “Decolonization Can't Just Be a Metaphor." Africa Is A Country [article], 11 December 2019. Available at https:/africasacountry.com/2019/11/ decolonization-cant-just-be-a-metaphor (accessed 1 April 2021).

Viso, Olga. 2017. "Learning in Public: An Open Letter on Sam Durant's Scaffold." Walker Art Center [letter], 26 May 2017. Available at https://walkerart.org/ magazine/learning-in-public-an-open-letter-on-sam-durants-scaffold (accessed 1 April 2021).

Viso, Olga. 2018. "Decolonizing the Art Museum: The Next Wave." The New York Times [opinion], 1 May 2018. Available at https://www.nytimes.com/2018/05/01/ opinion/decolonizing-art-museums.html (accessed 1 April 2021). 